\title{
IMPLEMENTASI DATA MINING MENGGUNAKAN ALGORITMA APRIORI UNTUK MENENTUKAN ATURAN ASOSIASI PADA PENJUALAN SUKU CADANG SEPEDA MOTOR DI PT.AHASS AGUNG MOTOR MALANG
}

\author{
Poepy Tri Handayani ${ }^{1}$, Harunur Rosyid $^{2}$ \\ 1) PT. Ahass Agung Motor \\ 2) Teknik Informatika, UniversitasMuhammadiyah Gresik \\ Email:poepytri@gmail.com
}

\begin{abstract}
ABSTRAK
PT. Ahass Agung Motor adalah perusahaan otomotif konsumen yang mencakup suku cadang otomotif konsumen dan jasa kendaraan bermotor. Suku cadang adalah bagian penting dari manajemen rantai pasokan. Penjualan merupakan salah satu faktor penting dalam mendukung keberlangsungan operasional di PT. Ahass Agung Motor. Untuk itu diperlukan suatu sistem yang dapat membantu menentukan pola pembelian konsumen. Dengan menggunakan data transaksi penjualan, sistem ini dapat dijadikan solusi yang tepat untuk meningkatkan kecepatan proses penentuan Frequent Itemset, Membentuk 3 itemset dari 2 itemset, menghitung nilai support dan confidence serta membentuk aturan asosiasi 2- itemset dan 3-itemset. Berdasarkan tabel analisis data transaksi penjualan tahun 2017 terdapat aturan yang memiliki tingkat dukungan tertinggi pada setiap periode dari tiga pengujian dengan aturan 3 itemset yaitu \{Dop kfv, Kampas kph $\} \rightarrow\{$ Kampas kzl $\}$ sedangkan yang tertinggi rule 2 itemset adalah $\{$ Pad set kwb 601 $\} \rightarrow\{$ Pad set kvb T-01\} yang memiliki korelasi atau hubungan positif dengan nilai korelasi $\geq 1$.
\end{abstract}

Kata Kunci :Data Mining, Frequent Itemset, Confidence, Support, Metode Apriori

\section{PENDAHULUAN}

PT. Ahass Agung Motor adalah perusahaan otomotif yang mencakup usaha distribusi dan retail, suku cadang otomotif konsumen, layanan kendaraan bermotor dan layanan keuangan. Onderdil atau suku cadang adalah komponen dari mesin yang dicadangkan untuk perbaikan atau penggantian bagian kendaraan yang mengalami kerusakan. Suku cadang merupakan bagian penting dalam manajemen rantai suplai. Penjualan merupakan salah satu faktor penting dalam menunjang keberlangsungan operasional di PT. Ahass Agung Motor. Permasalahan PT. Ahass Agung Motor dalam transaksi data yang sangat banyak, sehingga mengalami kesulitan mencari barang yang diperlukan pada saat itu, karena kurang optimalnya tata letak barang yang ada di tempat tersebut, untuk itu diperlukan suatu sistem yang dapat membantu menentukan pola pembelian konsumen. Algoritma apriori adalah algoritma market basket analysis yang digunakan untuk menghasilkan associationrule, dengan pola "if then". Market basket analysis merupakan salah satu teknik dari data mining yang mempelajari tentang perilaku kebiasaan konsumen dalam membeli barang secara bersamaan. Teknik tersebut bisa diterapkan dalam penjualan.

\section{LANDASAN TEORI 2.1Data Mining}

Secara sederhana, data mining merupakan ekstraksi informasi yang tersirat dalam sekumpulan data. Data mining merupakan sebuah proses untuk menggali kumpulan data dan menemukan informasi di dalamnya. (Turban, dkk, 2005). Data mining merupakan pengekstrakan informasi dari jumlah kumpulan data yang besar dengan menggunakan algoritma dan teknik gambar dari statistik, mesin pembelajaran dan sistem manajemen database. Data mining yang disebut juga dengan KnowledgeDiscovery in Database (KKD). Istilah data mining sering dipakai, mungkin karena istilah ini lebih pendik dari Knowledge Discovery in Database. Sebenarnya kedua istilah tersebut memiliki konsep yang berbeda, tetapi berkaitan satu sama lain. Data mining dianggap hanya sebagai suatu langkah terpenting dalam KDD. Proses KDD secara garis besar dapat dijelaskan sebagai berikut (Han \& Kamber, 2006).

1. Data Cleaning, proses menghapus data yang tidak konsisten dan kotor

2. Data Integration, penggabungan beberapa sumber data

3. Data Selection, pengambilan data yang akan dipakai dari sumber data 
INDEXIA: Informatic and Computational Intelegent Journal

Poepy Tri Handayani, Harunur Rosyid

Implementasi Data Mining Menggunakan Algoritma Apriori Untuk Menentukan Aturan Asosiasi Pada Penjualan Suku Cadang Sepeda Motor Di Pt.Ahass Agung Motor Malang

4. Data Transformation, proses dimana data ditransformasikan menjadi bentuk yang sesuai untuk diproses dalam data mining

5. Data Mining, suatu proses yang penting dengan melibatkan metode untuk menghasilkan suatu pola data

6. Pattern Evaluation, proses untuk menguji kebenaran dari pola data yang mewakili knowledge yang ada didalam data itu sendiri

7. Knowledge Presentation, proses visualisasi dan teknik menyajikan knowledge digunakan untuk menampilkan knowledge hasil mining kepada user.

\subsection{Teknik-teknik/jenis-jenis Data Mining}

\section{Market Basket Analysis}

Market basket analysis memanfaatkan data transaksi penjualan untuk dianalisis sehingga dapat ditemukan pola berupa item-item yang sering dibeli bersama ke dalam sebuah area yang berdekatan, merancang tampilan item-item di katalog, merancang kupon diskon (untuk diberikan kepada pelanggan yang membeli item tertentu).

2. Memory-based Reasoning

Metode klasifikasi yang digabungkan dengan penalaran berbasis memori proses menggunakan satu set untuk membuat model dari prediksi atau asumsi-asumsi yang dapat dibuat tentang objek baru yang diperkenalkan.

3. Cluster Detection

Ada dua pendekatan untuk clustering. Pendekatan pertama adalah dengan mengasumsikan bahwa sejumlah cluster sudah tersimpan dalam data tujuannya adalah untuk memecah data ke dalam cluster. Pendekatan lain disebut clustering aglomerative.

4. Link Analysis

Proses mencari dan membangun hubungan antara object dalam kumpulan data juga mencirikan sifat yang terkait dengan hubungan antara dua object.

5. Rule Induction

Ekstrasi aturan sebab-akibat dari data secara static, identifikasi aturan yang tersimpan di dalam data.

6. Neural Networks

Model prediksi non linier yang melakukan pembelajaran melalui latihan dan menyerupai struktur jaringan neural yang terdapat pada makhluk hidup.

\subsection{Analisis Asosiasi Apriori}

Analisis asosiasi berguna untuk menemukan hubungan penting yang tersembunyi di antara set data yang sangat besar. Hubungan yang sudah terbuka dipresentasikan dalam bentuk aturan asosiasi atau set aturan item yang sering muncul. Isu penting dalam analisis asosiasi adalah bagaimana cara menemukan pola tertentu dari data yang

berjumlah sangat besar, yang membuat biaya komputasi menjadi sangat mahal.

Dalam algoritma apriori semakin kecil nilai minimum support, semakin banyak rule yang dihasilkan tetapi tidak semua rule yang dihasilkan valid, yang menunjukkan bahwa nilai minimum support berpengaruh pada pembentukan rule tetapi tidak banyak berpengaruh terhadap kevalidan rule. Semakin kecil nilai minimum confidence, semakin banyak rule yang dihasilkan dan besar kemungkinan rule tersebut valid, yang menunjukkan bahwa nilai minimum confidence berpengaruh pada kevalidan rule. Dari rule-rule yang memenuhi nilai confidence dihitung nilai lift atau interest factor rasionya, rule yang memiliki nilai lift rasio atau interest factor lebih dari 1 maka rule tersebut valid dan bisa dijadikan rekomendasi. (Rizqi, 2010).

\subsection{Tahapan Association Rules}

Analisis asosiasi dikenal juga sebagai salah satu teknik data mining yang menjadi dasar dari berbagai teknik data mining lainnya. Khususnya salah satu tahap dari analisis asosiasi yang disebut analisis pola frekuensi tinggi(frequent pattern mining) menarik perhatian banyak peneliti untuk menghasilkan algoritma yang efisien. (Muhammad Ikhsan et al, 2007).

Metodologi dasar analisis terbagi menjadi dua tahap

a. Analisa pola frekuensi tinggi

Tahap ini mencari kombinasi item yang memenuhi syarat miminum dari nilai support dalam database. Nilai support item diperoleh dengan persamaan support (dukungan) merupakan suatu ukuran yang menunjukkan seberapa besar tingkat dominasi suatu item atau itemset dari keseluruhan transaksi.

Nilai support 1 item diperoleh dari rumus berikut :

Support $(\mathrm{A})=\frac{\text { jumlah transaksi mengandung A }}{\text { Jumlah transaksi }}$

Nilai support 2 item diperoleh dari rumus berikut : Support $(\mathrm{A}, \mathrm{B})=$ jumlah transaksi mengandungA, B

b. Pembentukan Aturan Asosiatif

$$
\text { Jumlah transaksi }
$$

Setelah semua pola frekuensi tinggi ditemukan barulah dicari aturan asosiatif yang memenuhi syarat minimum untuk confidence dengan menghitung aturan asosiatif $\mathrm{A} \rightarrow \mathrm{B}$ diperoleh dari rumus berikut :

Confidence $=\underline{\text { Jumlah transaksi mengandung } A \& B}$

$$
\text { Jumlah transaksi mengandung } A
$$

\section{ANALISIS DAN PERANCANGAN SISTEM}

\subsection{Analisis Sistem}

Analisis sistem adalah penguraian suatu sistem yang utuh ke dalam bagian-bagian komponennya yang bertujuan untuk mengidentifikasi dan menganalisa suatu 
INDEXIA: Informatic and Computational Intelegent Journal

Poepy Tri Handayani, Harunur Rosyid

Implementasi Data Mining Menggunakan Algoritma Apriori Untuk Menentukan Aturan Asosiasi Pada Penjualan Suku

Cadang Sepeda Motor Di Pt.Ahass Agung Motor Malang

permasalahan, kesempatan, hambatan yang terjadi dan kebutuhan yang diharapkan sehingga dapat diusulkan perbaikannya. PT. Ahass Agung Motor adalah perusahaan otomotif yang mencakup usaha distribusi dan retail, suku cadang. Dalam penjualan yang ada di PT. Ahass Agung Motor, data penjualan yang selalu bertambah tidak terpakai dengan baik. Semakin menumpuk nya data yang begitu banyak, sehingga mengalami kesulitan mencari barang yang diperlukan pada saaat itu, karena kurang optimalnya tata letak barang yang ada di tempat tersebut. Maka dari itu penentuan pola pembelian produk suku cadang diperlukan sebuah sistem yang baik agar dapat mencapai sesuai target yang telah ditentukan.Adapun diagram alirnya seperti gambar dibawah ini :

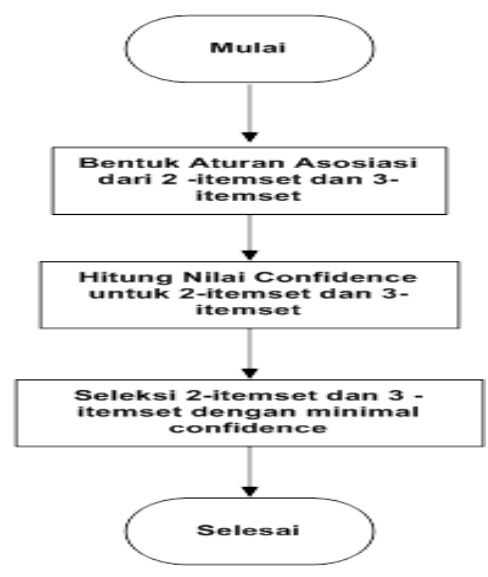

Gambar 1 Diagram Alir proses Pembentukan Aturan Asosiasi

\subsection{Perhitungan Metode Apriori}

Berdasarkan dari gambaran umum beserta tahapantahapan dijelaskan diatas maka sistem dapat dijelaskan dalam proses seperti dibawah ini:

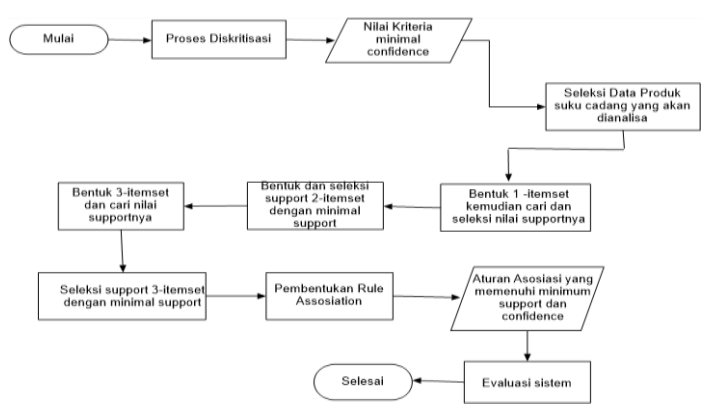

Gambar 2 Diagram Alir Proses Analisis Produk Suku cadang

3.3 Perancangan Sistem Data Flow Diagram (DFD) Level 0

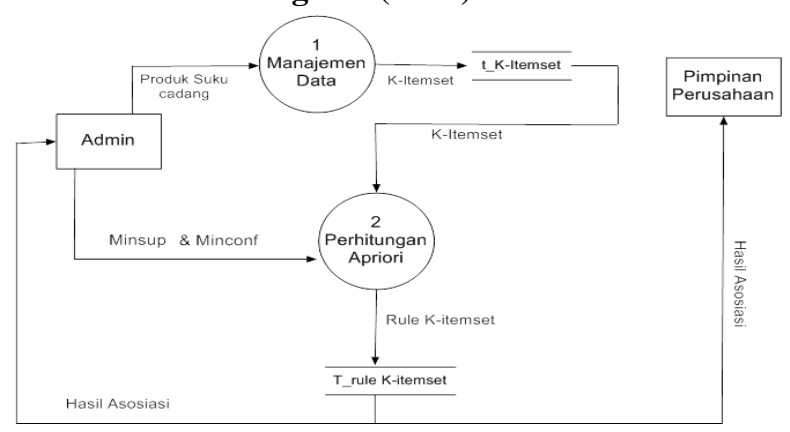

Gambar 3DFD Level 0

\section{Data Flow Diagram (DFD) Level 1}

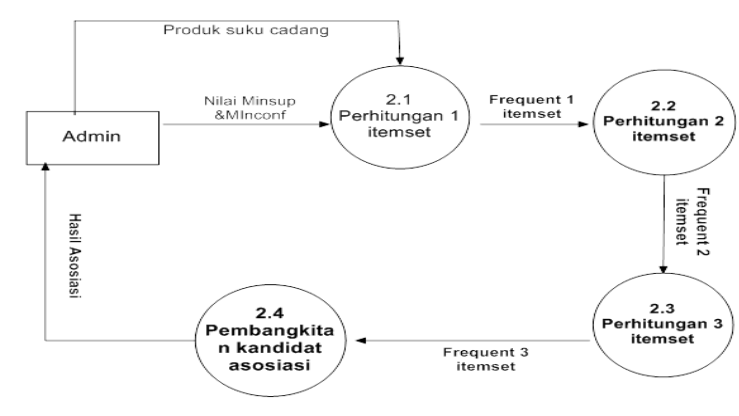

Gambar 3 DFD Level 1

4. IMPLEMENTASI DAN PENGUJIAN SISTEM 4.1 ImplementasiAntarmuka

a. Tampilan Login

Ketika admin akan melakukan analisa, maka login terlebih dahulu. Dapat dilihat pada Gambar 4.

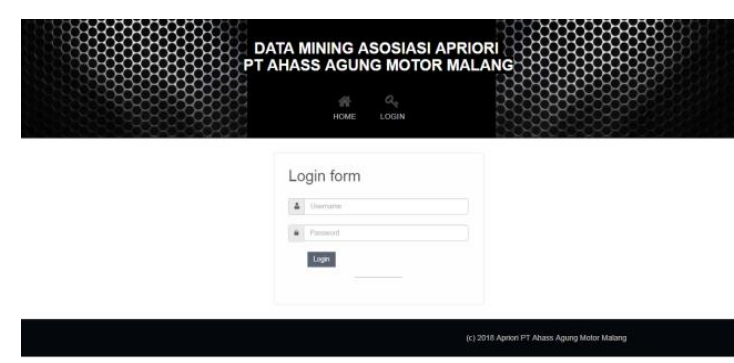

Gambar 4Tampilan Login

\section{b. Tampilan Menu Master Data}

Menu master data terdiri dari beberapa submenu yaitu home, data transaksi, proses apriori, hasil rule dan logout. Menu data transaksi digunakan untuk menginput data transaksi penjualan, menu proses apriori digunakan untuk proses perhitungan apriori dan menu hasil rule menampilkan hasil rule yang diperoleh dari proses perhitungan apriori. Tampilan dari menu master data dapat dilihat pada gambar 5 di bawah ini. 
INDEXIA: Informatic and Computational Intelegent Journal

Poepy Tri Handayani, Harunur Rosyid

Implementasi Data Mining Menggunakan Algoritma Apriori Untuk Menentukan Aturan Asosiasi Pada Penjualan Suku Cadang Sepeda Motor Di Pt.Ahass Agung Motor Malang

\section{Gambar 5 Tampilan Menu Master Data}

\section{c. Tampilan Proses Apriori}

Menu proses apriori ini akan melakukan perhitungan dimuali dari 1 itemset sampai perhitungan nilai confidence. Yang pertama dilakukan yaitu dengan memilih nilai minsup (30, 25 dan 35) dan minconf (60, 75 dan 70) dalam kotak pilihan dan tanggal yang akan dianalisa. Setelah itu baru melakukan proses dan menampilkan hasil proses apriori tersebutTampilan dari proses apriori bisa dilihat pada gambar 6 dibawah ini :

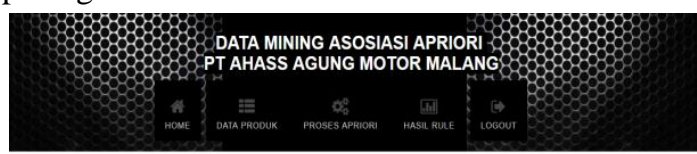

Proses Apriori

wan asport
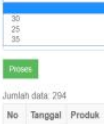

\subsection{PengujianSistem}

Pada pengujian ini sistem diuji dalam memproses data transaksi penjualan tertentu. Dari data transaksi yang dimasukan yang berjumlah 294 data akan diproses pencarian 1 itemset dan mencari nilai support kemudian menyeleksi dengan nilai minsup yang telah ditentukan setelah itu akan menghasilkan frequent 1 itemset. Dari hasil frequent dicari kombinasi 2 itemset dan menghitung nilai support kemudian menyeleksinya dengan minsup,hasil dari 2 itemset yang lolos akan dikombinasikan menjadi 3 itemset dan dilakukan perhitungan nilai support kemudian diseleksi dengan minsup, setelah menghasilkan frequent 3 itemset maka selanjutnya dilakukan proses aturan asosiasi dimana dari frequent 2 dan 3 itemset akan dicari nilai confidence dan menyeleksinya dengan minconf, Dan nantinya rule yang dihasilkan akan diperoleh sesuai dengan urutan atau id produk yang dianalisa.

Selain menghitung nilai confidence dan menghasilkan aturan asoisasi pada pengujian penentuan pola pembelian produk suku cadang disini dilakukan juga pengujian korelasi dari setiap rule yang terbentuk. Proses pengujian korelasi dengan menggunakan korelasi lift untuk menentukan apakah setiap aturan pengujianya memiliki korelasi positif atau korelasi negatif. Apabila dari perhitungan tersebut menghasilkan nilai dibawah 1 maka terdapat korelasi negatif . untuk perhitungan yang menghasilkan nilai diatas 1 maka terdapat korelasi positif. Namun apabila menghasilkan nilai sama dengan 1 maka tidak ada korelasi antara X dan Y.

Tabel 1 Tabel Pengujian Sistem pada MinSupport $30 \%$ dan MinConfidence $60 \%$

\begin{tabular}{|c|c|}
\hline Analisis produk & $\mathbf{2 0 1 7}$ \\
\hline Jumlah transaksi & 294 \\
\hline Nilai MinSup & $30 \%$ \\
\hline Nilai MinConf & $60 \%$ \\
\hline Jumlah 1 Itemset & 37 \\
\hline Jumlah 2 Itemset & 43 \\
\hline Jumlah 3 Itemset & 2 \\
\hline Jumlah Rule Asosiasi & 12 \\
\hline
\end{tabular}

Untuk pengujian sistem pada tahun 2017 dengan Minimal Support 30\% dan Minimal Confidence 60\% dari jumlah 294 transaksi diketahui bahwa jumlah dari itemset 1 yang lolos berjumlah 37 data dari itemset 2 berjumlah 43 data dan dari itemset 3 berjumlah 2 data yang lolos. Serta hasil Rule Asosiasi berjumlah 12 data yang hasilnya diatas $60 \%$.

Tabel 2 Tabel Aturan Asosiasi 2 Itemset yang memenuhi Minsup 30\% dan MinConf 60\%

\begin{tabular}{|c|l|c|c|c|}
\hline No & \multicolumn{1}{|c|}{ X => Y } & $\begin{array}{c}\text { Support } \\
\text { X U Y }\end{array}$ & $\begin{array}{c}\text { Support } \\
\mathbf{X}\end{array}$ & $\begin{array}{c}\text { Confi } \\
\text { dence }\end{array}$ \\
\hline 1 & $\begin{array}{l}\text { Dop kph } \\
\text { => pad set } \\
\text { kvb-T01 }\end{array}$ & 11.90 & 19.05 & 62.50 \\
\hline 2 & $\begin{array}{l}\text { Pad set } \\
\text { kwb 601 } \\
\text { => pad set } \\
\text { kvb-T01 }\end{array}$ & 13.27 & 17.35 & 76.47 \\
\hline 3 & $\begin{array}{l}\text { Dop kph } \\
\text { => dop kfv }\end{array}$ & 11.56 & 19.05 & 60.71 \\
\hline 4 & $\begin{array}{l}\text { Kampas } \\
\text { kph => dop } \\
\text { kfv }\end{array}$ & 13.61 & 22.45 & 60.61 \\
\hline 5 & $\begin{array}{l}\text { Dop stop } \\
\text { => dop } \\
\text { kota }\end{array}$ & 12.59 & 18.71 & 67.27 \\
\hline 6 & $\begin{array}{l}\text { Kampas } \\
\text { kph => } \\
\text { kampas kzl }\end{array}$ & 16.67 & 22.45 & 74.24 \\
\hline
\end{tabular}


INDEXIA: Informatic and Computational Intelegent Journal

Poepy Tri Handayani, Harunur Rosyid

Implementasi Data Mining Menggunakan Algoritma Apriori Untuk Menentukan Aturan Asosiasi Pada Penjualan Suku Cadang Sepeda Motor Di Pt.Ahass Agung Motor Malang

Tabel 3 Korelasi Aturan Asosiasi dengan Minsup 30\% dan Minconf 60\%

\begin{tabular}{|c|c|c|c|c|}
\hline No & $\mathbf{X}=>\mathbf{Y}$ & $\begin{array}{c}\text { Confid } \\
\text { ence }\end{array}$ & $\begin{array}{c}\text { Nilai } \\
\text { Uji } \\
\text { lift }\end{array}$ & $\begin{array}{c}\text { Korelas } \\
\text { i rule }\end{array}$ \\
\hline 1 & $\begin{array}{l}\text { Kampas kzl, } \\
\text { kampas kph } \\
\text { => pad set } \\
\text { kvb - T01 }\end{array}$ & 63.2653 & 1.8058 & $\begin{array}{c}\text { korelasi } \\
\text { positif }\end{array}$ \\
\hline 2 & $\begin{array}{l}\text { Kampas kph, } \\
\text { pad set kvb - } \\
\text { T01 => } \\
\text { kampas kzl }\end{array}$ & 79.4872 & 2.1638 & $\begin{array}{c}\text { korelasi } \\
\text { positif }\end{array}$ \\
\hline 3 & $\begin{array}{l}\text { Kampas kzl, } \\
\text { dop kfv => } \\
\text { kampas kph }\end{array}$ & 73.3333 & 3.2667 & $\begin{array}{c}\text { korelasi } \\
\text { positif }\end{array}$ \\
\hline 4 & $\begin{array}{l}\text { Dop kfv, } \\
\text { kampas kph } \\
\text { =>kampas kzl }\end{array}$ & 82.5000 & 2.2458 & $\begin{array}{c}\text { korelasi } \\
\text { positif }\end{array}$ \\
\hline 5 & $\begin{array}{l}\text { Kampas kph, } \\
\text { kampas kzl } \\
\text { => dop kfv }\end{array}$ & 67.3469 & 2.1064 & $\begin{array}{c}\text { korelasi } \\
\text { positif }\end{array}$ \\
\hline 6 & $\begin{array}{l}\text { Dop kph => } \\
\text { pad set kvb - } \\
\text { T01 }\end{array}$ & 62.5000 & 1.7840 & $\begin{array}{c}\text { korelasi } \\
\text { positif }\end{array}$ \\
\hline 7 & $\begin{array}{l}\text { Dop stop => } \\
\text { pad set kvb - } \\
\text { T01 }\end{array}$ & 60.0000 & 3.3329 & $\begin{array}{c}\text { korelasi } \\
\text { positif }\end{array}$ \\
\hline 8 & $\begin{array}{l}\text { Pad set kwb } \\
601=>\text { pad } \\
\text { set kvb - T01 }\end{array}$ & 79.5918 & 2.2718 & $\begin{array}{c}\text { korelasi } \\
\text { positif }\end{array}$ \\
\hline 9 & $\begin{array}{l}\text { Dop kph => } \\
\text { dop kfv }\end{array}$ & 60.7143 & 1.8989 & $\begin{array}{l}\text { korelasi } \\
\text { positif }\end{array}$ \\
\hline
\end{tabular}

pada nilai minimum support, yaitu nilai prosentase minimal yang menunjukkan seberapa besar tingkat dominasi suatu atribut produk (item) atau kumpulan atribut (itemset) terhadap keseluruhan data transaksi yang dianalaisa dan nilai minimum confidence, yaitu nilai prosentase minimal yang menunjukkan hubungan dari kaidah asosiasi.

2. Dalam algoritma apriori semakin kecil nilai minimum support, semakin banyak rule yang dihasilkan tetapi tidak semua rule yang dihasilkan valid, yang menunjukkan bahwa nilai minimum support berpengaruh pada pembentukan rule tetapi tidak banyak berpengaruh terhadap kevalidan rule, semakin kecil nilai minimum confidence, semakin banyak rule yang dihasilkan dan besar kemungkinan rule tersebut valid, yang menunjukkan bahwa nilai minimum confidence berpengaruh pada kevalidan rule. Dari rule-rule yang memenuhi nilai confidence dihitung nilai lift rasionya, rule yang memiliki nilai lift rasio lebih dari 1 maka rule tersebut valid dan bisa dijadikan rekomendasi untuk strategi penjualan suku cadang di PT.Ahass Agung Motor.

3. Terdapat korelasi lift positif dari pengujian analisa rule yang telah terbentuk pada tahun 2017.

\subsection{Analisis Hasil Pengujian Sistem}

Dari hasil pengujian proses penentuan pola pembelian produk suku cadang oleh konsumen dengan metode apriori dapat diketahui analisis hasil sebagai berikut:

1. Hasil keluaran (output) perangkat lunak berupa informasi tentang bagaimana pola pembelian konsumen yang sering terjadi di PT.Ahass Agung Motor yang didasarkan

\begin{tabular}{|c|l|l|l|l|}
\hline 10 & $\begin{array}{l}\text { Kampas } \\
\text { kph => } \\
\text { dop kfv }\end{array}$ & 60.6061 & 1.8956 & $\begin{array}{l}\text { korelasi } \\
\text { positif }\end{array}$ \\
\hline 11 & $\begin{array}{l}\text { Dop stop } \\
\text { => dop } \\
\text { kota }\end{array}$ & 67.2727 & 2.7470 & $\begin{array}{l}\text { korelasi } \\
\text { positif }\end{array}$ \\
\hline 12 & $\begin{array}{l}\text { Kampas } \\
\text { kph => } \\
\text { kampas } \\
\text { kzl }\end{array}$ & 74.2424 & 2.0210 & $\begin{array}{l}\text { korelasi } \\
\text { positif }\end{array}$ \\
\hline
\end{tabular}


INDEXIA: Informatic and Computational Intelegent Journal

Poepy Tri Handayani, Harunur Rosyid

Implementasi Data Mining Menggunakan Algoritma Apriori Untuk Menentukan Aturan Asosiasi Pada Penjualan Suku

Cadang Sepeda Motor Di Pt.Ahass Agung Motor Malang

\section{SIMPULAN DAN SARAN}

5.1 Kesimpulan

Berdasarkan hasil implementasi dan pengujian sistem maka dalam penelitian tugas akhir ini dapat disimpulkan sebagai berikut :

1. Metode apriori dapat mencari pola pembelian produk suku cadang yang dilakukan oleh konsumen di PT. Ahass Agung Motor dengan perhitungan yang sudah dijelaskan. Sehingga dari hasil tersebut pemilik perusahaan akan lebih mudah untuk membuat strategi penjulan seperti dalam penataan barang yang ada di perusahaan.

2. Ada 12 rule pada tahun 2017 yang memiliki korelasi atau hubungan yang positif dengan nilai korelasi $\geq 1$

3. Pola yang didapat dari 3 itemset adalah $\{$ kampas kzl, dop kfv $\} \rightarrow\{$ kampas kph\} sedangkan dari rule 2 itemset adalah $\{$ pad set kwb $601 \rightarrow$ pad set kvb $-\mathrm{T} 01\}$.

4. Nilai minimum support dan minimum confidence yang terbaik adalah pengujian pertama dengan minimum support $30 \%$ dan minimum confidence $60 \%$.karena memiliki rule paling banyak, rule yang memiliki nilai lift rasio lebih dari 1 maka rule tersebut valid dan bisa dijadikan rekomendasi untuk strategi penjualan suku cadang di PT. Ahass Agung Motor Malang.

\subsection{Saran}

Adapun saran yang ingin disampaikan penulisan terhadap penelitian tugas akhir ini adalah :

1. Aplikasi penentuan pola pembelian produk suku cadang yang terjual bersama dengan Menggunakan Metode Apriori 
INDEXIA: Informatic and Computational Intelegent Journal

Poepy Tri Handayani, Harunur Rosyid

Implementasi Data Mining Menggunakan Algoritma Apriori Untuk Menentukan Aturan Asosiasi Pada Penjualan Suku Cadang Sepeda Motor Di Pt.Ahass Agung Motor Malang

Untuk Keperluan Bisnis Teori dan Aplikasi :

Graha Ilmu Yogyakarta.

Turban, E., dkk. (2005). Decision Support System and

Intelligent Systems : Andi

Offset.

Yanto, Roby., \& Riri Khoiriah. Implementasi Data

Mining Dengan Metode Algortima Apriori

Dalam menentukan Pola Pembelian Obat :

Lubuklingau. 